\title{
Use of hierarchical designs to detect scales of heterogeneity in the invasive species Sargassum muticum
}

\author{
CELIA OLABARRIA ${ }^{1}$, FRANCESCA ROSSI ${ }^{2}$, IVAN F. RODIL ${ }^{1}$, PATRICIA QUINTAS ${ }^{1}$ \\ and JESÚS S. TRONCOSO ${ }^{1}$ \\ ${ }^{1}$ Departamento de Ecoloxía e Bioloxía Animal, Universidad de Vigo, Campus Lagoas-Marcosende, \\ 36310 Vigo (Pontevedra), Spain. E-mail: colabarria@uvigo.es \\ ${ }^{2}$ IMAR - Institute of Marine Research (C.I.C.), Department of Zoology, Faculty of Sciences and Technology, \\ University of Coimbra, 3004-517, Coimbra, Portugal.
}

\begin{abstract}
SUMMARY: Invasion of alien species poses serious threats to many ecosystems. Despite the potential of Sargassum muticum to spread and invade new areas, no attention has been given to the study of variability of structural or morphological features across different spatial scales. We employed a hierarchical sampling design to examine patterns of spatial variability of fertility and morphological variables of $S$. muticum over different spatial scales (quadrats, sites, locations, rias) ranging from metres to tens of kilometres. We repeated the sampling in March, April and July to test for the consistency of patterns through time. There was no variability between rias (tens of kilometres apart), but substantial differences occurred at the other scales examined. Fertility and percent cover varied between locations (1.5-3 km apart), whereas morphological variables varied between sites (tens of metres apart) and quadrats (metres apart). Furthermore, patterns of variation were not consistent over time. The study demonstrated the importance of a multi-scale sampling programme for monitoring seaweed invasion.
\end{abstract}

Keywords: spatial scale, morphology, fertility, distribution, invasion success, Galician coast, Sargassum muticum.

RESUMEN: USO DE DISEÑOS JERÁRQUICOS EN LA DETECCIÓN DE ESCALAS DE HETEROGENEIDAD EN LA ESPECIE INVASORA SARGASSUM MUTICUM. - Las especies invasoras representan una seria amenaza para muchos ecosistemas. A pesar del potencial de Sargassum muticum para extenderse e invadir nuevas áreas, no se ha dedicado ninguna atención al estudio de la variabilidad de las características estructurales o morfológicas a diferentes escalas espaciales. Hemos usado un diseño de muestreo jerárquico para examinar patrones de variabilidad espacial de las variables fenológicas y morfológicas de S. muticum a diferentes escalas espaciales (cuadrantes, sitios, localidades, rías) que van desde unos pocos metros a decenas de kilómetros. Repetimos el muestreo en marzo, abril y julio para comprobar la consistencia de los patrones a lo largo del tiempo. No hubo variabilidad entre rías (decenas de kilómetros de separación), pero se encontraron diferencias sustanciales a otras escalas. La fertilidad y el porcentaje de cobertura variaron entre localidades $(1.5-3 \mathrm{~km})$ y tiempo, mientras que las variables morfológicas variaron entre sitios (decenas de metros) y cuadrantes (metros). Asimismo, los patrones de variabilidad no fueron consistentes en el tiempo. El estudio demostró la importancia de los programas de muestreo utilizando múltiples escalas espaciales para el seguimiento de algas invasoras.

Palabras clave: escala espacial, morfología, fertilidad, distribución, éxito de invasión, costa de Galicia, Sargassum muticum.

\section{INTRODUCTION}

Alien seaweeds and plants have increasingly arrived in new areas during the last few decades (Ver- laque, 2001). Alien species are widely recognised as important agents of global change, and can colonise new habitats and even cause local extinction of native species (Vitousek et al., 1997). Such invasions 
have serious effects not only on biodiversity per se, but also on the management and restoration of natural ecosystems.

A primary recommendation for designing monitoring programmes for effective habitat protection and restoration is that they should be based on sampling schemes at the spatial and temporal scales that characterise population and community dynamics of the species of interest. Therefore, we first need to identify the spatial and temporal scale(s) at which there is consistent and predictable variation in the variable(s) of interest. Hierarchical sampling programmes can identify these patterns of variability and provide the necessary information for effective monitoring programmes (e.g. Underwood and Chapman, 1998).

In the context of alien seaweeds, hierarchical sampling programmes may be used to identify patterns of species distribution and to develop better management strategies (Pauchard et al., 2003). In particular, we need to identify temporal fluctuations and spatial distribution of variables related to population dynamics and morphological characteristics of these species, as these patterns may be linked to invasion success.

Scales of spatial and temporal variations in the reproduction mode or growth rate of alien seaweeds may vary according to environmental heterogeneity, including the distribution of intra- and interspecific competitors (e.g. Mooney and Drake, 1986; Rejmanek and Richardson, 1996). Environmental heterogeneity (spatial, temporal and invader-driven) may increase the probability of coexistence between alien and native species, thereby reducing the negative impact on native populations and assemblages (Spector and Putz, 2006). Furthermore, phenotypic plasticity of physiological traits can modify the ability of some species to invade (Horton and Neufeld, 1998; Spector and Putz, 2006). This is typical of seaweeds which have the potential to adjust their form and function to the immediate environment (e.g. Viejo et al., 1995; Fernández, 1999; Engelen et al., 2005). For example, Engelen et al. (2005) showed that size and biomass of Sargassum polyceratium Collins (Taylor) individuals varied depending on wave exposure and depth. Moreover, Fernández (1999) reported different cycles of growth and reproduction of S. muticum depending on the vertical position on the shore.

Sargassum muticum (Yendo) Fensholt is native to SE Asia, but its present distribution includes Europe, the Mediterranean Sea and the west coast of North America (Britton-Simmons, 2004). This species invaded northern Spain in the 1980s (Pérez-Cirera et al., 1989); it was first observed on the Galician coast in 1986 (see Pérez-Cirera et al., 1989) and has since successfully colonised most of the Galician rias (sensu Vilas et al., 2005). The capacity of this species to spread and invade new areas seems to rely on a high reproductive potential and its ability to drift. The alga is monoecious, self-fertile and highly fecund (Norton, 1977), and possesses vesicles that allow the annually produced fronds to continue to float if detached. These fronds are able to survive and become fertile as they drift, thus increasing the potential for long-range dispersal. Viejo et al. (1995) reported different growth rates in exposed and sheltered areas. As environmental conditions and biological and/or physical processes vary within and between intertidal shores at different scales (e.g. Dayton and Tegner, 1984; Menge, 1995), it may be expected that percent cover and some $S$. muticum traits (such as branching frequency, length of primary lateral and fertility) will vary according to the spatial scale of heterogeneity.

Despite the ability of Sargassum muticum to spread and invade new areas, very few studies have focused on the description of spatial patterns of distribution of this species (but see Stæhr et al., 2000; Harries et al., 2007). Furthermore, no attention has been given to variability in structural, or morphological features (e.g. biomass, diameter of holdfast, density and number of laterals, length of primary lateral) across different spatial scales. So far, most studies have focused on physiology, autoecology or effects of $S$. muticum on the intertidal and subtidal assemblages (e.g. Andrew and Viejo, 1998; Arenas et al., 2002; Britton-Simmons, 2004). Not many studies have examined the existence of patchiness in distribution and phenology of S. muticum within invaded areas (but see Fernández, 1999).

In this paper, we used a hierarchical sampling design to identify scales of spatial variation of phenological and morphological traits of the fucoid alga Sargassum muticum (Yendo) Fensholt on the Galician coast. We specifically examined patterns of variability of percent cover, fertility, size of primary lateral and total number of laterals of $S$. muticum over a variety of spatial scales, ranging from metres to tens of kilometres, and the consistency of these patterns over time. 


\section{MATERIAL AND METHODS}

\section{Study area and sampling design}

The study was carried out on the south region of the Galician coast, at the low-shore (0.4-0.8 m above the lowest astronomical tide) of the intertidal areas sited at the left side of two rias, Ría de Aldán $\left(42^{\circ} 20^{\prime} \mathrm{N} ; 8^{\circ} 51^{\prime \prime} \mathrm{W}\right)$ and Ría de Vigo $\left(42^{\circ} 10^{\prime} \mathrm{N}\right.$; $8^{\circ} 51^{\prime \prime} \mathrm{W}$ ), located $18 \mathrm{~km}$ apart (Fig. 1). In this region, the intertidal zone is dominated by the invasive seaweed Sargassum muticum and the native algae Bifurcaria bifurcata Ross, Corallina officinalis Linnaeus, Saccorhiza polyschides (Lightfoot) Batters and diverse encrusting and turf-forming seaweeds (personal observation).

The sampling design included three scales of spatial variability, ranging from metres within a shore to tens of kilometres between rias. Within each ria we chose three locations 1.5-3 km apart. Locations were characterised by well-developed Sargassum muticum beds and a similar type of substrate, i.e. gently sloping granitic rocky shores. Locations varied slightly in terms of wave exposure, ranging from semi-exposed to sheltered locations (Alvarez-Salgado et al., 1993). Within each location, we selected two sites 10-40 m apart. At each site, we randomly sampled six $0.25 \mathrm{~m}^{2}$ quadrats at least $1.5 \mathrm{~m}$ apart along a marked transect running parallel to the coastline.

Each site was sampled in March, April and July 2006, the period of greatest cover of Sargassum muticum. Sampling was not carried out in autumn and winter, as the over-wintering structure consists only of a holdfast with a main axis (3-9 $\mathrm{mm})$.

\section{Sampling methods}

Estimates of percent cover were carried out with a $50 \times 50 \mathrm{~cm}$ quadrat divided into $5 \times 5 \mathrm{~cm}$ subquadrats. Percent cover was estimated by registering the presence/absence of Sargassum muticum individuals at each of the 81 intersections of the $5 \times 5$ $\mathrm{cm}$ sub-quadrats of a $50 \times 50 \mathrm{~cm}$ quadrat. Within each quadrat the number of laterals per thallus and the length, i.e. size, of the longest primary lateral of 6 haphazardly selected $S$. muticum thalli was recorded. Fertility in each quadrat was estimated as the percentage of thalli bearing receptacles.

Visual observations are less precise than more quantitative methods, but are often preferred when large areas must be surveyed at relatively low cost.
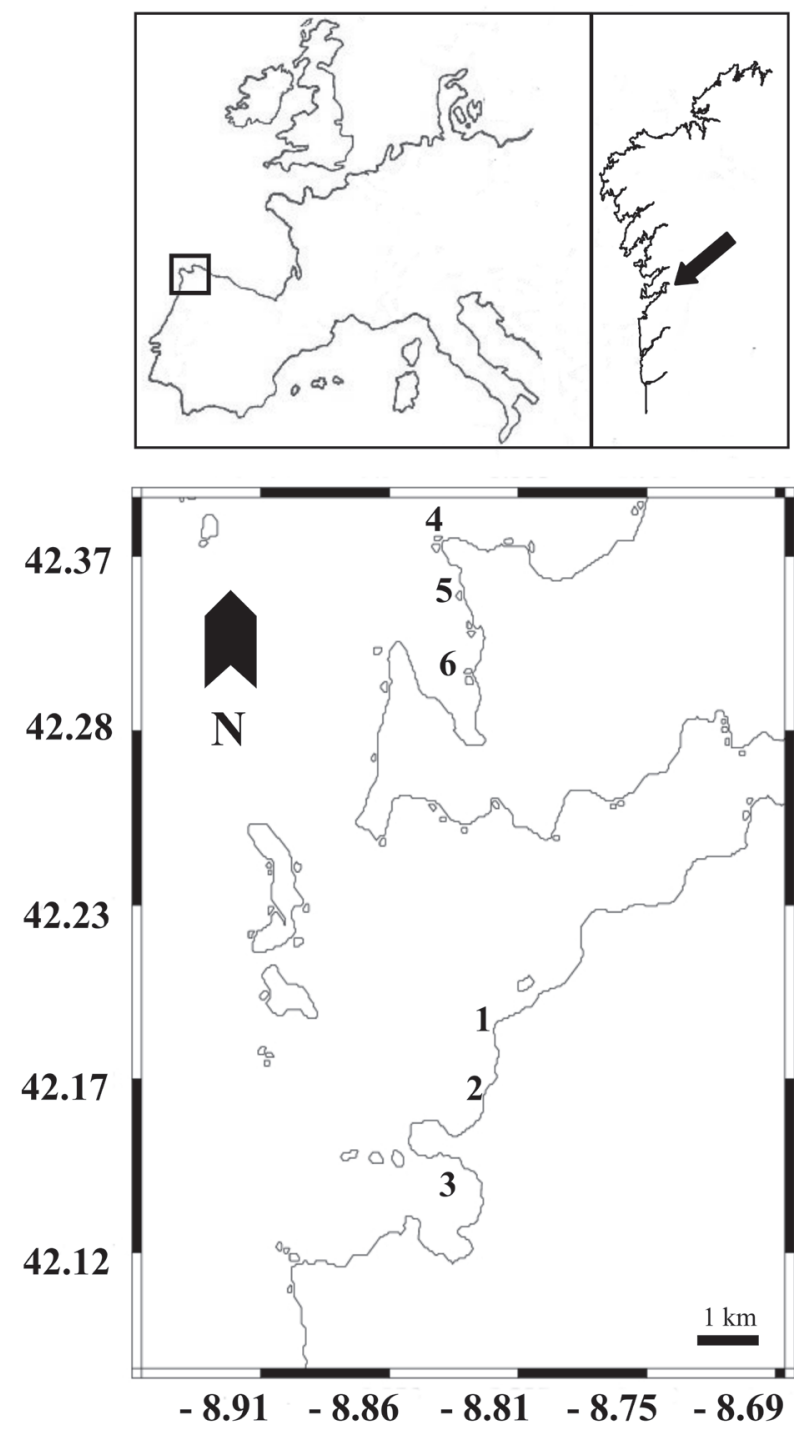

FIG. 1. - The study area and position of the locations within the two rias. Location 1: Canido; location 2: Cabo Estai; location 3: Monte Lourido; location 4: Cabo Udra; location 5: Areas de Bon; location 6: Menduiña.

Subjective methods have the potential problem that variability among samplers may be a significant source of variation. A comparison among different samplers investigating the same quadrat showed that estimates of algal cover diverged by \pm 5 to $10 \%$ depending on the abundance. Potential error in the data was minimal, as the same two persons performed all surveys.

\section{Statistical analysis}

All variables were analysed separately at each sampling time, using nested analyses of variance (ANOVA). Phenological variables (percent cover, fertility) were analysed with ria (2 levels), location 
TABLE 1. - Summary of comparisons between rias (E), locations (L), sites (S) and quadrats for all variables using nested ANOVAs. All factors were random

\begin{tabular}{|c|c|c|c|c|c|c|c|c|c|c|c|c|c|}
\hline $\begin{array}{l}\text { (a) Phenology } \\
\text { Source of variation }\end{array}$ & Df & $\underset{F}{\operatorname{March}}$ & $P$ & $\begin{array}{c}\text { ercent co } \\
\text { April } \\
\text { F }\end{array}$ & $P$ & $\begin{array}{c}\text { July } \\
\text { F }\end{array}$ & $P$ & $\underset{F}{\operatorname{March}}$ & $P$ & $\begin{array}{l}\text { Fertility } \\
\text { April } \\
\text { F }\end{array}$ & $P$ & $\begin{array}{c}\text { July } \\
\text { F }\end{array}$ & $P$ \\
\hline $\begin{array}{l}\text { Rias } \\
\text { Locations (E) } \\
\text { Sites (L(E)) } \\
\text { Residual } \\
\text { Transformation }\end{array}$ & $\begin{array}{c}1 \\
4 \\
6 \\
108\end{array}$ & $\begin{array}{l}1.51 \\
4.61 \\
2.99 \\
\\
\text { None }\end{array}$ & $\begin{array}{l}>0.05 \\
<0.05 \\
<0.01\end{array}$ & $\begin{array}{c}1.69 \\
* 3.09\end{array}$ & $\begin{array}{l}>0.05 \\
<0.05\end{array}$ & $\begin{array}{c}0.19 \\
6.78 \\
0.6 \\
\\
\text { None }\end{array}$ & $\begin{array}{l}>0.05 \\
<0.05 \\
>0.05\end{array}$ & $\begin{array}{c}0.02 \\
77.28 \\
0.05\end{array}$ & $\begin{array}{l}>0.05 \\
<0.001 \\
>0.05\end{array}$ & $\begin{array}{l}0.38 \\
2.87 \\
2.7\end{array}$ & $\begin{array}{l}>0.05 \\
>0.05 \\
<0.05\end{array}$ & $\begin{array}{l}1.08 \\
9.96 \\
1.08 \\
\\
\text { None }\end{array}$ & $\begin{array}{l}>0.05 \\
<0.01 \\
>0.05\end{array}$ \\
\hline $\begin{array}{l}\text { (b) Morphology } \\
\text { Source of variation }\end{array}$ & Df & $\underset{F}{\operatorname{March}}$ & $\begin{array}{l}\text { Len } \\
P\end{array}$ & $\begin{array}{l}\text { th of prir } \\
\text { April } \\
\text { F }\end{array}$ & $\begin{array}{l}\text { nary late } \\
\qquad P\end{array}$ & $\underset{\mathrm{F}}{\text { July }}$ & $P$ & $\underset{F}{\operatorname{March}}$ & $\mathrm{Nu}$ & $\begin{array}{c}\text { mber of lat } \\
\text { April } \\
\text { F }\end{array}$ & $\begin{array}{l}\text { terals } \\
\qquad P\end{array}$ & $\begin{array}{c}\text { July } \\
\text { F }\end{array}$ & $P$ \\
\hline $\begin{array}{l}\text { Rias } \\
\text { Location (E) } \\
\text { Sites (L(E)) } \\
\text { Quadrats (S(L(E))) } \\
\text { Residual }\end{array}$ & $\begin{array}{c}1 \\
4 \\
6 \\
60 \\
360\end{array}$ & $\begin{array}{l}0.01 \\
5.15 \\
2.47 \\
2.54\end{array}$ & $\begin{array}{l}>0.05 \\
<0.05 \\
<0.05 \\
<0.001\end{array}$ & $\begin{array}{l}0.03 \\
3.54 \\
5.01 \\
4.34\end{array}$ & $\begin{array}{l}>0.05 \\
>0.05 \\
<0.001 \\
<0.001\end{array}$ & $\begin{array}{l}1.35 \\
0.54 \\
2.42 \\
4.92\end{array}$ & $\begin{array}{l}>0.05 \\
>0.05 \\
<0.05 \\
<0.001\end{array}$ & $\begin{array}{l}0.38 \\
0.74 \\
6.04 \\
1.61\end{array}$ & $\begin{array}{l}>0.05 \\
>0.05 \\
<0.001 \\
<0.01\end{array}$ & $\begin{array}{l}0.59 \\
2.53 \\
5.02 \\
1.61\end{array}$ & $\begin{array}{l}>0.05 \\
>0.05 \\
<0.001 \\
<0.01\end{array}$ & $\begin{array}{l}0.46 \\
3.65 \\
2.76 \\
3.56\end{array}$ & $\begin{array}{l}>0.05 \\
>0.05 \\
<0.05 \\
<0.001\end{array}$ \\
\hline Transformation & & Sqrt $(x+1$ & & Sqrt (x+ & & Sqrt $(x+1$ & & $\log (x+1$ & & $\log (x+1)$ & & $\log (x+1$ & \\
\hline
\end{tabular}

* Sites (L(E)) was eliminated and its sums of squares pooled with Residual (i.e. non-significant at $P=0.25$ ) (Underwood, 1997).

(3 levels, nested in ria) and site (2 levels, nested in location) as random factors. Morphological variables (length of primary lateral, number of laterals) were analysed including quadrat (6 levels nested in site) as an additional random factor. Data were also analysed including time of sampling (3 levels, random) as an orthogonal factor to test for spatio-temporal interactions. The homogeneity of variance was examined using Cochran's $C$-test before running the analysis. Data were $\log (\mathrm{x}+1)$ or square-root transformed when necessary to normalise their distribution and to remove heteroscedasticity (Underwood, 1997). To determine which scales were associated with the greatest variability, the components of variation on each spatial scale were independently calculated from the mean square estimates (Underwood, 1997). Where a component of variation was estimated to be negative, it was removed from the model and the mean square estimates were re-calculated for the remaining factors (Fletcher and Underwood, 2002). The terms eliminated from the model are presented as zero variance in the results section.

\section{RESULTS}

Both phenological (percent cover and fertility) and morphological (length of primary lateral and number of laterals) variables showed significant differences in their mean values for at least one of the spatial scales analysed (Table 1a). Overall, percent cover and fertility varied among locations (e.g. 1.5-3 $\mathrm{km}$ apart), except for fertility in April, which varied at the scale of sites (Table 1a). In addition, there were
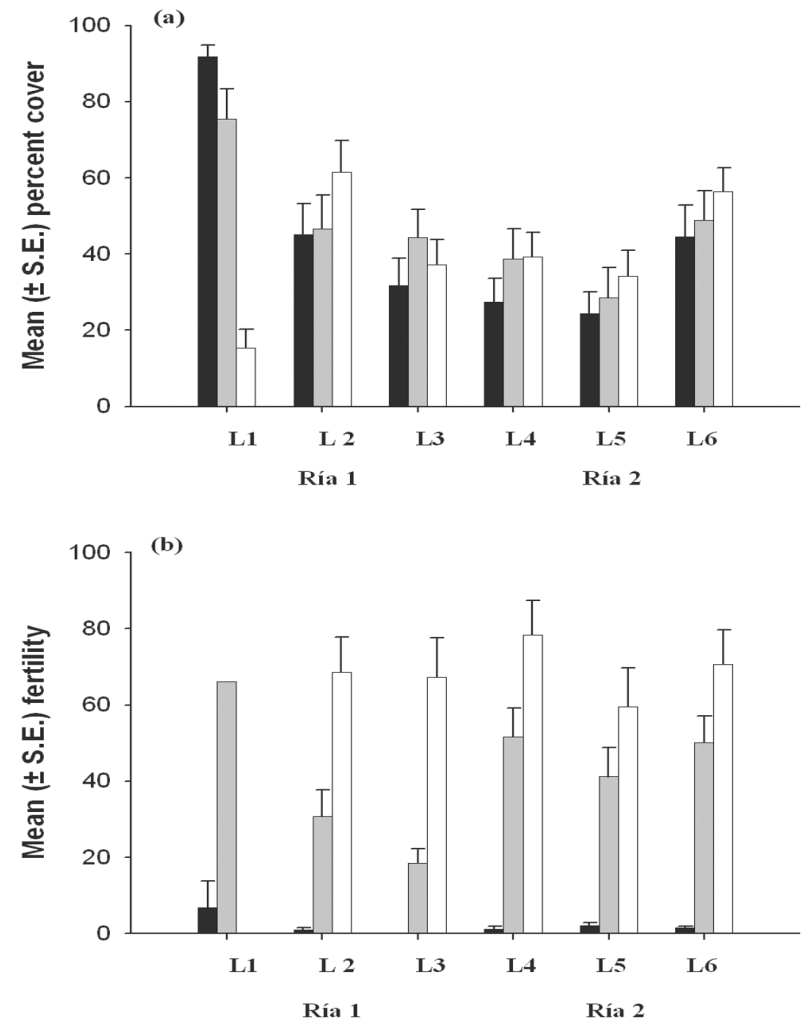

FIG. 2. - Temporal variation of phenological variables at 'location' scale $(n=20)$. Mean $( \pm$ S.E.) of (a) percent cover and (b) fertility at each of the 3 locations (L1-L6) within the two rias (Ría de Vigo and Ría de Aldán). Black, grey and white bars represent March, April and July, respectively. 

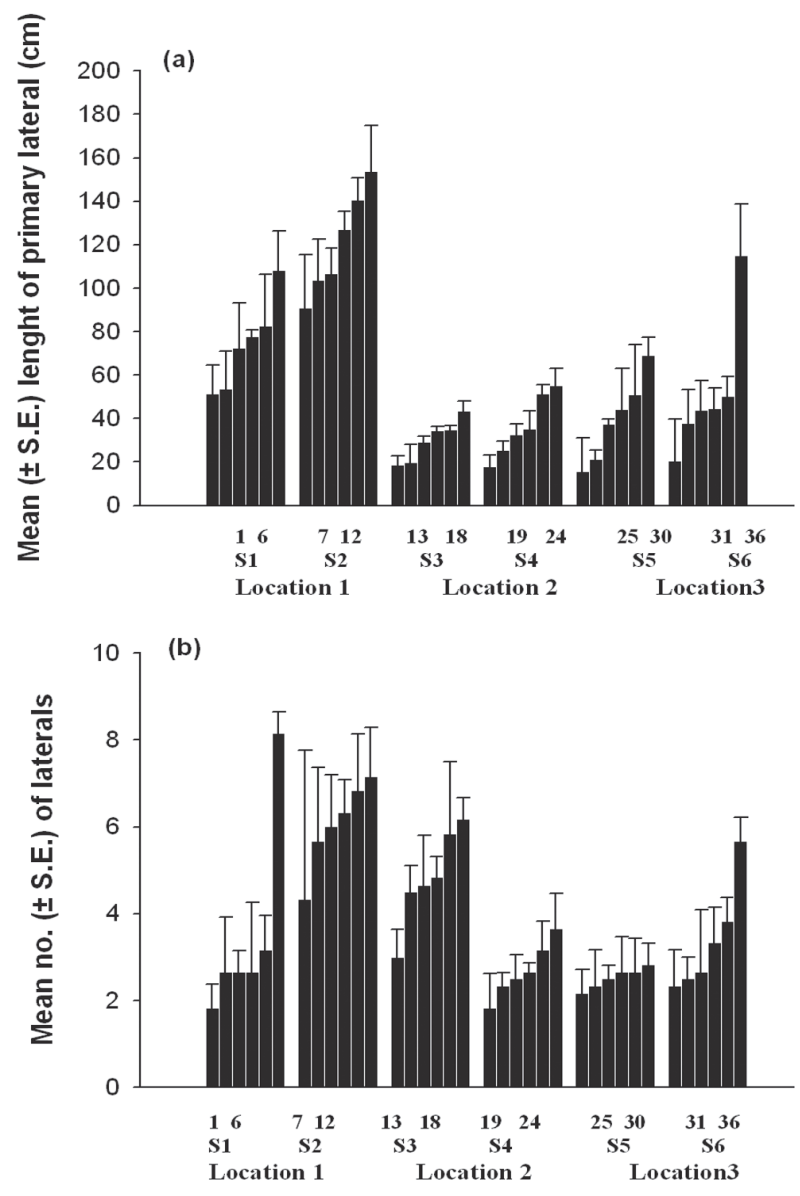

FIG. 3. - Variation of morphological variables at quadrat scale $(n=6)$. Mean $( \pm$ S.E. $)$ of (a) length of primary lateral $(\mathrm{cm})$ and $(b)$ number of laterals in each of the 6 quadrats $(\mathrm{Q})$ within the 2 sites (S1-S6) in the 3 locations at Ría de Vigo (Ria 1). Only March is represented.

significant interactions between locations and times of sampling (percent cover: $\mathrm{F}_{8,12}: 5.31, P<0.01$, SNK tests, $P<0.05$, Fig. 2a; Fertility: $\mathrm{F}_{8,12}: 8.96 ; P<0.001$, SNK tests, $P<0.05$, Fig. 2 b), due to the different temporal pattern found at Location 1 within the Ría de Vigo (L1 in Fig. 2). This location showed the greatest early percent cover in March and it was the only location where this percent cover decreased in July (SNK tests, $P<0.05$, Fig. 2a). At the same location, fertility of $S$. muticum decreased until the absence of reproductive plants in July, though July represented the time with the highest percentage of reproductive thalli at all the other locations (Fig. 2b).

Morphological variables varied among sites and quadrats (Table 1b). Variability at the scale of location was only significant in March, when primary laterals were longer in specimens from Location 1 within the Ría de Vigo (Location 1 in Fig. 3a). Location 1 also had the largest variability in the number of laterals between quadrats and sites (Fig. 3b). There were significant interactions between times of sampling and the spatial scales, from locations to quadrats. For length of primary lateral, the spatio-temporal interaction was both at the quadrat $\left(\mathrm{F}_{120,1080}: 3.44, P<0.001\right.$, SNK tests, $P<0.05)$ and the location scale $\left(\mathrm{F}_{8,12}: 3.07\right.$, $P<0.05$; SNK tests, $P<0.05$, Fig. $4 \mathrm{a}$ ), whereas for the number of laterals, the interaction was at the quadrat $\left(\mathrm{F}_{120,1080}: 2.26, P<0.001\right.$, SNK tests, $\left.P<0.05\right)$ and the site scale $\left(\mathrm{F}_{12,120}: 5.03, P<0.001\right.$; SNK tests, $P<0.05$, Fig. 4b).

The largest contribution to the total variation always originated from the smallest scale analysed. For fertility and percent cover, the largest variation was found at the scale of quadrats within sites, whereas morphological variables showed the largest variation at the scale of thalli within quadrats. These averaged ( \pm SE) $76 \pm 11 \%$ for percent cover, $75 \pm 6 \%$ for fertility, $49 \pm 7 \%$ for length of primary lateral and $69 \pm 7 \%$ for number of laterals (averaged across the 3 times of sampling). An important result was that some of the
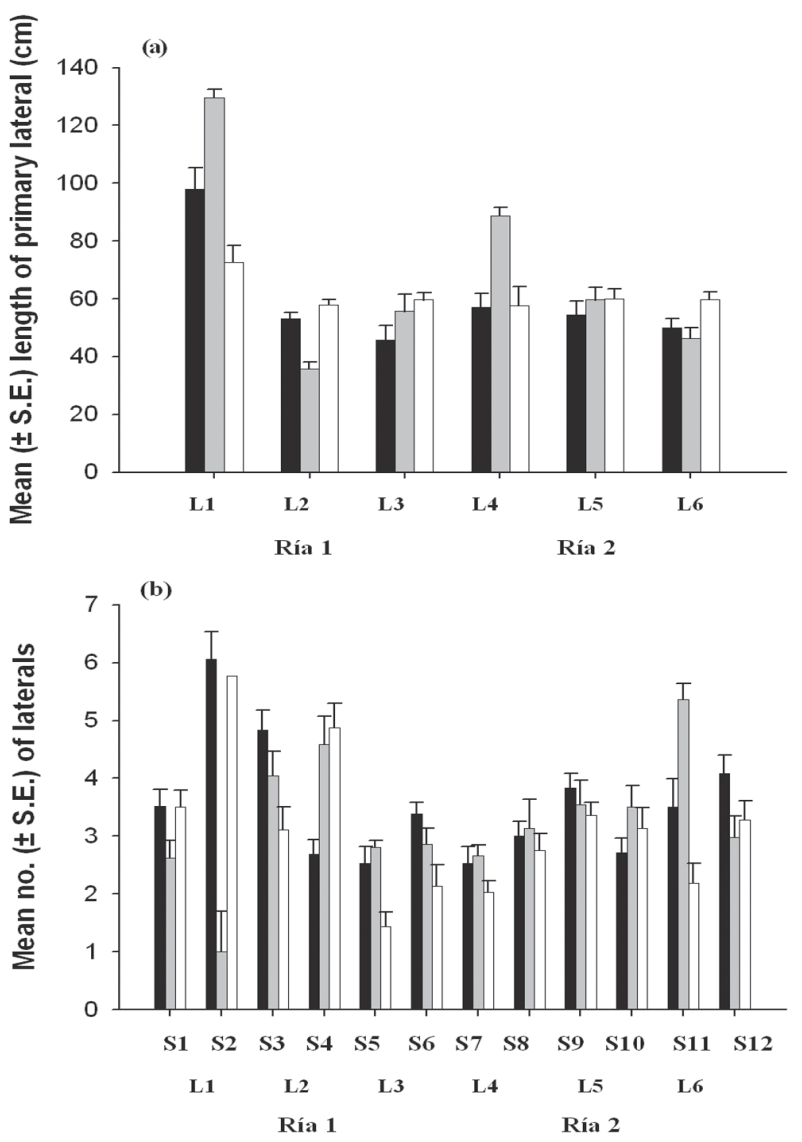

FIG. 4. - Temporal variation of morphological variables at location and site scales, respectively. Mean ( \pm S.E.) of (a) length of primary lateral $(\mathrm{cm})$ at each of the 3 locations within the 2 rias $(\mathrm{n}=72)$ and (b) number of laterals at each of the 2 sites, at the 3 locations within the 2 rias $(n=36)$. Black, grey and white bars represent March, April and July, respectively. Ria 1: Ría de Vigo; Ria 2: Ría de Aldán. 
(a)

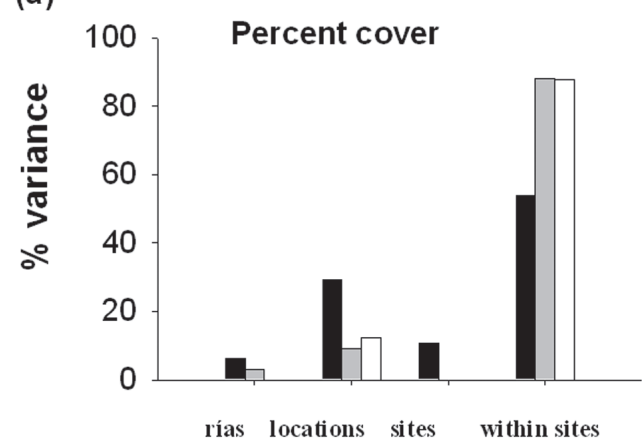

(c)

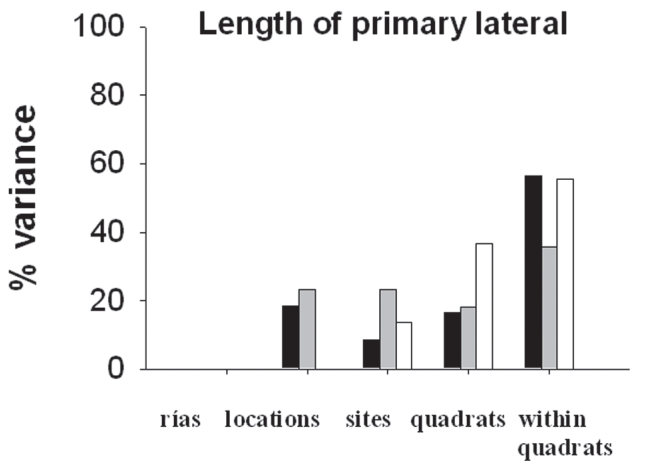

(b)

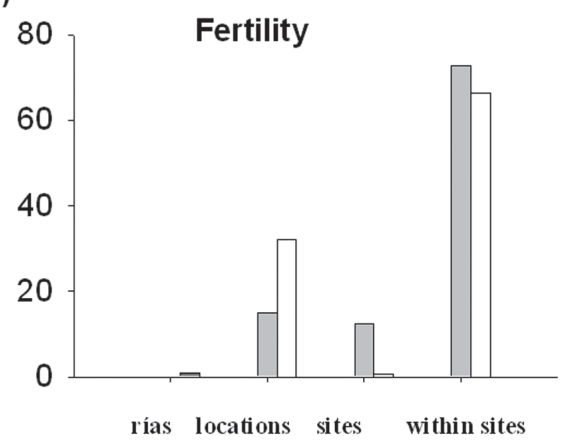

(d)

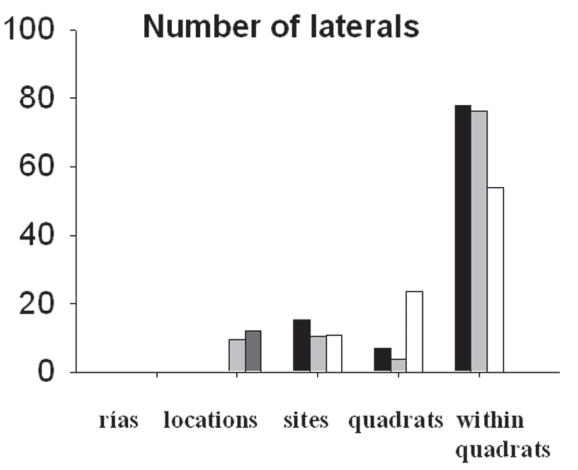

FIG. 5. - Components of variation at 4 (phenological variables) and 5 (morphological variables) spatial scales show variation in different variables. (a) Percent cover, (b) fertility, (c) length of primary lateral and (d) number of laterals. Overall variation is partitioned among scales and expressed as a percentage of the total. Negative variance components were converted to 0. Black, grey and white bars represent March, April and July, respectively.

estimates were negative, indicating that the spatial variability at the largest scales was underestimated (Fig. 5). For percent cover and fertility, 3 of the 24 comparisons (averaged across the 3 times of sampling) gave negative values for the variances between rias and 3 gave negative values for the variances between sites (Figs. 5a, b), whereas for morphological variables 6 of 30 comparisons gave negative values for the variances between rias and 2 gave negative values for the variances between locations (Figs. 5c, d).

\section{DISCUSSION}

When the scales at which variation occurs are not known in advance, sampling using nested designs can identify the relevant scales of variability to be incorporated into further research (Underwood, 1997; Underwood and Chapman, 1998). Using a hierarchical sampling programme we identified the scales of greatest spatial variability and tested their consistency through time, which is also fundamental to make hypotheses on the possible processes regulating invasiveness of Sargassum muticum. We also demonstrated the importance of multi-scale sam- pling schemes when S. muticum invades new habitats. This is the first study to consider multiple scales of variability in the morphological and phenological patterns of $S$. muticum.

We found evidence that substantial differences in all variables analysed occurred at a variety of spatial scales. Simple sampling procedures are thus not informative enough on the real ecological status of the species, because Sargassum muticum spreads in patches of different size, depending on the variables of interest (e.g. Fernández, 1999). The phenological state of this species (e.g. percent cover and fertility) varied at relatively large scales $(\mathrm{km})$, whereas morphological parameters were consistently variable among sites. Phenology and morphology also showed patchiness at the smallest scales analysed (i.e. between quadrats, metres apart), indicating that an array of both large-scale and very local processes may affect its reproduction and morphology.

Processes that facilitate or inhibit invasion are likely to operate at different spatial scales (Stohlgren et al., 1999). Information on the patterns of variability may provide indications on the processes responsible for the invasion. The meso-scale variability (among locations) in the phenology was very 
likely related to differences in the environmental conditions of locations such as wave exposure, sediment rates or other processes correlated to sedimentation such as nutrient concentration (Schaffelke and Klump, 1997). Location 1 within Ría de Vigo was indeed characterised by less wave exposure, and a probable consequent increase in sedimentation and particulate organic deposition (see Josenfson and Conley, 1997). At this location, Sargassum muticum had the highest percent cover and fertility, but the fertile period reached its maximum earlier and was shorter (all plants returned to a vegetative state by early July). Although the effect of nutrient concentrations on seaweed reproduction is complex (Hoffmann and Santelices, 1991; Lüning, 1993; Sánchez and Fernández, 2006), studies on the Spanish coast showed that establishment, spread and fertility of $S$. muticum are enhanced by increased nutrient concentrations (Arenas et al., 1995; Arenas and Fernández, 1998). Furthermore, sedimentation can kill other seaweeds, especially those characterised by short thalli, inhibit recruitment of certain macroalgae (Isaeus et al., 2004), and thus liberate the space available for growth and reproduction of $S$. muticum. Similarly, sediment deposition can inhibit feeding behaviour of herbivorous species such as fishes, sea urchins or limpets (e.g. Airoldi and Hawkins, 2007), thereby changing the strength of grazing pressure on $\mathrm{S}$. $\mathrm{mu}$ ticum. In addition, the shortened period of fertility at Location 1 may be related to a local increase in temperature due to the minor exchange of water related to decreased hydrodynamism, which might have a negative effect on both growth and reproduction of $S$. muticum during summer (Plouguerné et al., 2006). Here, temperature increase in summer can overlap the effect of nutrient enrichment and reduce the length of the reproduction period.

Variability among sites and at the lowest scales in the morphological response variables might reflect local differences due to topography complexity, that can operate at the small scales of metres and even centimetres (e.g. sites or quadrats). For example, increased complexity can either create more numerous or different microhabitats available for the development of those species that can adapt to environmental changes or simply increase the availability of space and reduce competition with other species (Fernández, 1999; Piazzi et al., 2004).

Intraspecific competition and other densitydependent processes may also induce changes in morphology and reproduction at a small scale, i.e. $<2$ m (Andrew and Viejo, 1998; Arenas et al., 2002). Furthermore, the significance of this density-dependent regulation in the dynamics of Sargassum muticum populations might vary between different places according to other environmental factors such as hydrodynamism (Norton et al., 1981; Viejo et al., 1995). We found that S. muticum had the largest primary laterals and the greatest percent cover at the most sheltered location (Location 1 within the Ría de Vigo). At this location $S$. muticum also showed the largest variability at a small scale in morphological variables. Such variability may be the indirect result of less wave exposure, affecting percent cover and length of plants and thereby increasing the significance of density-dependent processes. Small-scale variability (metres to tens of metres), however, is never completely explained by ecological processes and stochastic variation is often called in to explain the residual variability that is not explained by the heterogeneity of the substratum (e.g. Underwood and Chapman, 1998).

The variation in both morphology and phenology at a small scale, i.e. between sites, can sometimes indicate that Sargassum muticum can have phenotypic adaptation to local environmental heterogeneity due to phenotypic plasticity and/or genetic differentiation. If different phenotypes are favoured in different environments, selection may either preserve genetic variation, assuming an insignificant gene flow, or lead to evolution plasticity (Jormalainen and Honkanen, 2004). This is an interesting consideration that should be further explored with reciprocal transplants of adult plants and zygotes, in order to determine whether genetic differentiation or phenotypic plasticity are the mechanisms driving such spatial variability.

In conclusion, it is highly likely that the scales of spatial variation that we have identified were due to a real difference in the ecological processes and/or synergism among processes operating at different spatial scales, but they might also indicate stochastic variations or variations that cannot be explained with the present ecological knowledge. This leads us to conclude that the development of Sargassum muticum in new habitats cannot be monitored using simplistic experimental designs, but will need a strategy that takes into account numerous scales of variability and both morphological and reproductive indices at the same time. Information on the repeatability of the patterns and their variation according to the reproductive and growing period of the alien species 
is the first step towards identifying the mechanisms that account for a successful invasion and proposing testable hypotheses that attempt to account for the observed patterns.

\section{ACKNOWLEDGEMENTS}

This research was supported by the Spanish Government through the Ministry of Education and Science (PROJECT CGL2005-02269). Funds to I.F. Rodil were provided by a predoctoral grant (XUGA, María Barbeito).

\section{REFERENCES}

Airoldi, L. and S.J. Hawkins. - 2007. Negative effects of sediment deposition on grazing activity and survival of the limpet Patella vulgata. Mar. Ecol. Prog. Ser., 332: 235-240.

Alvarez-Salgado, X.A., G. Rosón, F.F. Pérez and Y. Pazos. - 1993. Hydrographic variability off the Rías Baixas (NW Spain) during the upwelling season. J. Geophys. Res., 98: 14447-14455.

Andrew, N.L. and R.M. Viejo. - 1998. Effects of wave exposure and intraspecific density on the growth and survivorship of Sargassum muticum (Sargassaceae: Phaeophyta). Eur. J. Phycol., 33: 251-258.

Arenas, F. and C. Fernández. - 1998. Ecology of Sargassum muticum (Phaeophyta) on the North coast of Spain III. Reproductive ecology. Bot. Mar., 41: 209-216.

Arenas, F., C. Fernández, J.M. Rico, E. Fernández and D. Haya. - 1995. Growth and reproductive strategies of Sargassum muticum (Yendo) Fensholt and Cystoseira nodicaulis (Whit.) Roberts. Sci. Mar., 59: 1-8.

Arenas, F., R.M. Viejo and C. Fernández. - 2002. Density-dependent regulation in an invasive seaweed: responses at plant and modular levels. J. Ecol., 90: 820-829.

Britton-Simmons, K.H. - 2004. Direct and indirect effects of the introduced alga, Sargassum muticum (Yendo), in subtidal kelp communities of Washington State, USA. Mar. Ecol. Prog. Ser., 277: 61-78.

Dayton, P.K. and M.J. Tegner. - 1984. Catastrophic storms, El Niño, and patch stability in a southern California kelp community. Science, 224: 283-285.

Engelen, A.H., P. Åberg, J.L. Olsen, W.T. Stam and A.M. Breeman. -2005 . Effects of wave exposure and depth on biomass, density and fertility of the fucoid seaweed Sargassum polyceratium (Phaeophyta, Sargassaceae). Eur. J. Phycol., 40 (2): 149-158.

Fernández, C. - 1999. Ecology of Sargassum muticum (Phaeophyta) on the north coast of Spain: IV. Sequence of colonization on a shore. Bot. Mar., 42: 553-562.

Fletcher, D.J. and A.J. Underwood. - 2002. How to cope with negative estimates of components of variance in ecological field studies. J. Exp. Mar. Biol. Ecol., 273: 89-95.

Harries, D.B., S. Harrow, J.R. Wilson, J.M. Mair and D.W. Donnan. -2007 . The establishment of the invasive alga Sargassum muticum on the west coast of Scotland: a preliminary assessment of community effects. J. Mar. Biol. Ass. U.K., 87: 1057-1067.

Hoffmann, A.J. and B. Santelices. - 1991. Banks of algal microscopic forms: hypotheses on their functioning and comparisons with seed banks. Mar. Ecol. Prog. Ser., 79: 185-194.

Horton, J.L. and H.S. Neufeld. - 1998. Photosynthetic responses of Microstegium vimineum (Trin.) A. Camus, a shade-tolerant C4 grass, to variable light environments. Oecologia, 114: 11-19.

Isaeus, M., T. Malm, S. Persson and A. Svensson. - 2004. Effects of filamentous algae and sediment on recruitment and survival of Fucus serratus (Phaeophyceae) juveniles in the eutrophic Baltic Sea. Eur. J. Phycol., 39: 301-307.
Jormalainen, V. and T. Honkanen. - 2004. Variation in natural selection for growth and phlorotannins in the brown alga Fucus vesiculosus. J. Evol. Biol., 17: 807-820.

Josenfson, A.B. and D.J. Conley. - 1997. Benthic response to a pelagic front. Mar. Ecol. Prog. Ser., 147: 49-62.

Lüning, K. - 1993. Environmental and internal control of seasonal growth in seaweeds. Hydrobiologia, 260: 1-14.

Menge, B.A. - 1995. Indirect effects in marine rocky intertidal interaction webs: patterns and importance. Ecol. Monogr., 65: 21-74.

Mooney, J.A. and J.A. Drake. - 1986. Ecology of biological invasions of North America and Hawaii. Ecol. Stud., 58: 1-321.

Norton, T.A. - 1977. Ecological experiments with Sargassum muticum. J. Mar. Biol. Ass. U.K., 57: 33-43.

Norton, T.A., A.C. Mathieson and M. Neushul. - 1981. Morphology and environment. In: S. Lobban and M. Wynne (eds.), The biology of seaweeds, pp. 421-451. Blackwell Scientific Publications, Oxford.

Pauchard, A., P. Alaback and E. Edlund. - 2003. Plant invasions in protected areas at multiple scales: Linaria vulgaris (Scrophulariaceae) in the West Yellowstone area. West. N. Am. Nat., 63: 416-428.

Pérez-Cirera, J.L., J. Cremades and I. Bárbara. - 1989. Precisiones sistemáticas y sinecológicas sobre algunas algas nuevas para Galicia o para las costas atlánticas de la Península Ibérica. An. Jard. Bot. Madrid, 46: 35-45.

Piazzi, L., D. Balata, M. Pertusati and F. Cinelli. - 2004. Spatial and temporal variability of Mediterranean macroalgal coralligenous assemblages in relation to habitat and substratum inclination. Bot. Mar., 47: 105-115.

Plouguerné, E., K. Le Lann, S. Connan, G. Jechoux, E. Deslandes and V. Stiger-Pouvreau. - 2006. Spatial and seasonal variation in density, reproductive status, length and phenolic content of the invasive brown macroalga Sargassum muticum (Yendo) Fensholt along the coast of Western Brittany (France). Aquat. Bot., 85: 337-344.

Rejmanek, M. and D. M. Richardson. - 1996. What attributes make some plant species more invasive? Ecology, 77 (6): 1655-1661.

Sánchez, I. and C. Fernández.- 2006. Resource availability and invisibility in an intertidal macroalgal assemblage. Mar. Ecol. Prog. Ser., 313: 85-94.

Schaffelke, B. and D.W. Klump. - 1997. Growth of germling of the macroalga Sargassum baccularia (Phaeophyta) is stimulated by enhanced nutrients. Proceeding of the $8^{\text {th }}$ International Coral Reef Symposium, 2: 1839-1842.

Spector, T. and F.E. Putz. - 2006. Biomechanical plasticity facilitates invasion of maritime forests in the southern USA by Brazilian pepper (Schinus terebinthifolius). Biol. Inv., 8: 255-260.

Stæhr, P.A., F.M. Pedersen, M.S. Thomsen, Wernberg, T. and D. Krause-Jensen. - 2000. Invasion of Sargassum muticum in Limfjorden (Denmark) and its possible impact on the indigenous macroalgal community. Mar. Ecol. Prog. Ser., 207: 79-88.

Stohlgren, T.J., D. Binkley, G.W. Chong, M.A. Kalkhan, L.D. Schell, K.A. Bull, Y. Otsuki, G. Newman, M. Bashkin and Y. Son. - 1999. Exotic plant species invade hotspots of native diversity. Ecol. Monogr., 68: 25-46.

Underwood, A.J. - 1997. Experiments in ecology: their logical design and interpretation using analysis of variance. Cambridge University Press.

Underwood, A.J. and M.G. Chapman. - 1998. Spatial analyses of intertidal assemblages on sheltered rocky shores. Aust. J. Ecol., 23: $138-157$.

Verlaque, M. - 2001. Checklist of the macroalgae of Thau lagoon (Hérault, France), a hot spot of marine species introduction in Europe. Oceanol. Acta., 24: 29-49.

Viejo, R.M., J. Arrontes and N.L. Andrew. - 1995. An experimental evaluation of the effect of wave action on the distribution of Sargassum muticum in northern Spain. Bot. Mar., 38: 437-441.

Vilas, F., A. Bernabeu and G. Méndez. - 2005. Sediment distribution pattern in the Rias Baixas (NW Spain): main facies and hydrodynamic dependence. J. Mar. Syst., 54: 261-276.

Vitousek, P.M., H.A. Mooney, J. Lubchenco and J. Melillo. - 1997. Human domination of Earth's ecosystem. Science, 277: 494-499.

Scient. ed.: F. Maynou.

Received July 24, 2008. Accepted December 2, 2008. 